\title{
"Spatial Data Analysis for Ground Water Quality Assessment With Special Reference to Fluoride" - A Case Study of Dhar District, Madhya Pradesh, India
}

\author{
Dinesh Kumar Umak ${ }^{1}$, Sandeep Kumar Rastogi ${ }^{1}$, I. C. Das ${ }^{2}$ \\ ${ }^{1}$ M.P. Council of Science and Technology, Bhopal, India \\ ${ }^{2}$ NRSC, Hyderabad, India \\ Correspondence: Dinesh Kumar Umak, M.P. Council of Science and Technology, Bhopal, India.
}

Received: December 4, 2021 Accepted: January 25, 2022 Online Published: January 31, 2022

doi:10.5539/ijc.v14n1p8

URL: https://doi.org/10.5539/ijc.v14n1p8

\begin{abstract}
Water is a prime natural resource and physiological necessity to mankind. Therefore, drinking water must not carry harmful chemicals as well as biological contaminants for the well-being and human health. Some of the chemicals like Fluoride, Iron, Arsenic, Cadmium, Chromium, Lead, selenium, and Nitrate in water may produce serious physiological changes when exist beyond permissible concentration.

The Aim of the study was to create spatial map for drinking water purpose for Dhar district, MP. The ground water quality data were collected from PHED, M.P. and IMIS (Ministry of Drinking water \& Sanitation) Website, Government of India. The GWQ layers were created separately for each element for Pre-Monsoon and Post-Monsoon period from the well point layers with interpolation technique. Each element wise layer has been categorised into 'three catagories (1) potable water in Desirable limits (2) Potable water in permissible limits (3) non-potable ground water, as per BIS standard, 2015. The Union of eight element layers of each pre-monsoon and post-monsoon has been done and integrated pre-monsoon and Integrated post-monsoon Ground Water Quality (GWQ) map have been prepared and after the Union of these two maps, the Final ground water quality map has been prepared. It was concluded from the study, that multiple parameters are affecting the quality of ground water in Dhar district and particularly excess Fluoride, Nitrate, Total Hardness (as Caco3), Iron, pH, and Total Dissolve solids are prevalent in the area. About 69.66\% Habitation of Dhar district is severely affected mainly by excess of Fluoride, Nitrate \& Total Hardness (as Caco3), pH \& Iron(Fe) \& It is observed that about $70.51 \%$ area of Dhar district has been affected in terms of Ground Water Quality.
\end{abstract}

Keywords: Ground Water Quality (GWQ), Geographical Information System (GIS), Bureau of Indian Standard (BIS)

\section{Introduction}

An adequate quantity of safe drinking water of acceptable quality is the primary necessity of every human being. India has large Human settlements in rural areas and villages which face problems of water quality and quantity, available water resources and seasonal scarcity of water. The villages mainly depend upon surface water resources, dug well water or bore well water. Surface water usually pose problem of turbidity while the bore well may pose the problems of Hardness, Fluorides and dissolved Iron. It is therefore important from the water supply point of view that critical evaluation of water treatment system need to be done on the primary factors which include raw and treated water quality, local constraints and relative cost. Simple, versatile, cost effective and innovative water treatment systems are the primary need in India for their implementation in rural areas and villages for supply of adequate quantities of safe potable water. Remote Sensing \& GIS Techniques can support up to a great extent for Ground Water Quality mapping.

Dhar district situated in the south-western part of Madhya Pradesh covered area of 8145.31 sq.km. Falling in between $22^{\circ} 1^{\prime} 21.171^{\prime \prime}$ and $23^{\circ} 8^{\prime} 18.431$ "North Latitudes and $74^{\circ} 28^{\prime} 7.64^{\prime \prime}$ and $75^{\circ} 42^{\prime} 55.184 "$ East Longitude and falling in survey of India degree sheets no's 46J, 46M and 46N. It is bounded by Ratlam, west nimar (Khargoan), Indore and Jhabua District of Madhya Pradesh. Dhar is the district headquarters and Badnawar, Manawar, Kukshi and Sardarpur are the important towns. The total number of settlements lying in the Dhar district are 1824. The Highest temperate in summer rises up to $46^{\circ} \mathrm{C}$ temperature while minimum temperature during winter falls up to $5-6^{\circ} \mathrm{C}$.

\section{Data and Methodology}

The Ground water quality data Collected from PHED and downloaded from IMIS (India water)) website from 2009 to 
2017. The Survey of India Toposheets No's $46 \mathrm{~J} / 8, \mathrm{~J} / 10,11,12,13,14,15,16 ; 46 \mathrm{M} / 4,8$; and 46N/1, 2, 3, 4, 5, 6, 7, 8, 10, 11, 12 were used for creating a Thematic maps like Base map, Settlement \& roads etc. Indian Remote Sensing LISS III-P6 digital Satellite data of the year 2009-2010 for three seasons (January, April and October) were also used for the preparing the Geology, Geomorphology and lineament maps. District Resource Map (DRM) Published by Geological Survey of India (GSI) is also used for the reference.

The Ground Water Quality (GWQ) data were collected from IMIS \& PHED and organize the ground water quality data of pre and post monsoon season. The essential eight parameters are pH, Total Hardness, Iron, chloride, Fluoride, TDS, Nitrate, \& Alkalinity. Well Point layer of pre and post monsoon with their elements was generated. Element wise layers for pre monsoon and post monsoon data were created by using Inverse distance weighted analysis and classify into the desirable, permissible and non-Potable class as per Bureau of Indian Standard (BIS) 2015. By union of all Pre-monsoon layers and by union of all Post-monsoon layers, an integrated pre-monsoon and integrated post-monsoon ground water quality class map has been prepared. By union of these two maps final ground water quality class map of Dhar district has been prepared containing nine classes.

\section{Physiography and Geomorphology}

Physiographically, the district can be sub-divided into three major units viz Nothern plateau region (Malwa Plateau), central hilly region and Southern Valley (Narmada Valley). Malwa Plateau is an upland region characterised by undulating topography with elevations ranging from 350 to $550 \mathrm{~m}$. Chambal, Mahi and bagh rivers flowing Northerly drain this region. The central hilly region comprises ENE-WSW trending Ridges which have steep slopes and scarp faces on the southern side. The highest elevation in the district ie, $751 \mathrm{~m}$ above MSL is located in this region. The central hilly regions forms water divide between the Northward flowing rivers of Mahi and Chambal Drainage and the southward flowing tributaries of Narmada river including Baghain, uri, man and Karam rivers. The drainage Pattern in the Northern part is sub-dendritic to sub Parallel whereas it is dendritic with local sub parallel pattern in the southern part. The southern Valley region is occupied by Narmada river flowing from East to West along a mega Lineament.

The Geomorphology was referred from National Geomorphological and Lineament Mapping (NGLM) project on 1:50000 scale. The project was sponsored by National Remote Sensing Agency, Hyderabad and Geological Survey of India. The study area Dhar district comprises of the landforms namely as Upper Plateau (above $600 \mathrm{~m}$ ) and Lower Plateau (below $600 \mathrm{~m}$ ) from MSL, which is Highly, Moderately and Low dissected based on drainage as well as Joint and Fractures dissections, Plateau top, Ridge, Mesa, Butte, Scarp, Plateau Remnant and Valley of Structural origin. The other landforms such as, Pediment, Pediplain, Pediment corstone tor complex, Residual Mound and Gullied Land are of Denudational origin and Gullied Tract of, fluvial origin.

\section{Geology}

In the Dhar District the oldest litho- units belong to the Aravali super group of palaeo-proterozoic age (2500 m.y.) which comprises the Udaipur, Lunavada, and champaner group. Udaipur group consist of chlorite schist exposed NNW of Kukshi. Lunavada and champaner group occurs in the southern part. Lunavada group comprises muscovite, quartzite and biotite gneisses while the champaner group comprises slate, Phyllite and dolomite which are intruded by basic igneous bodies. Bijawar group of palaeo to meso Proterozoic age (2500 to 1600 m.y.) occurs east of gandhwani and comprises shale, Slate Phyllite, Dolomite and quartzite. Narmada valley granitoids of palaeo Proterozoic age are exposed along the main river and around gandhwani and included granite gneiss and granite with enclaves of hornblende gneiss and chlorite schist. These are intruded by metabasic and quartz veins. Bagh group of lower cretaceous age (110 m.y.) unconformably overlies the rocks of Aravali super group with exposed thickness verifying from 5 to $40 \mathrm{~m}$. This comprises Nimar sandstone at the base followed by the calcareous units comprising nodular limestone and coralline limestone. The calcareous unit is fossiliferrous and contained echinoids, lamellibranches, gastropods, corals and brachiopods. A major part of the district is occupied by Basalt flows of Malwa group of Deccan volcanic of late cretaceous Palaeogene (68-62 m.y.) Age. This comprises 38 Basaltic fiows with a total thickness of $610 \mathrm{~m}$. The rock is fine to medium grain, aphyric to sparsely to moderately porphyritic containing plagioclase phenocryst. Megacrystic flow units occur at the top part of the flows. The flows have been classified into Mandleshwar, Kalisindh, Kankaria, Pirukheri, Indore and Bargonda formations in ascending order of sequence. The Deccan trap and the Bagh beds have been intruded by a large number of basic, ultra-basic and carbonate dykes. The dykes are generally trend ENE-WSW to E-W parallel to the Narmada lineament. 

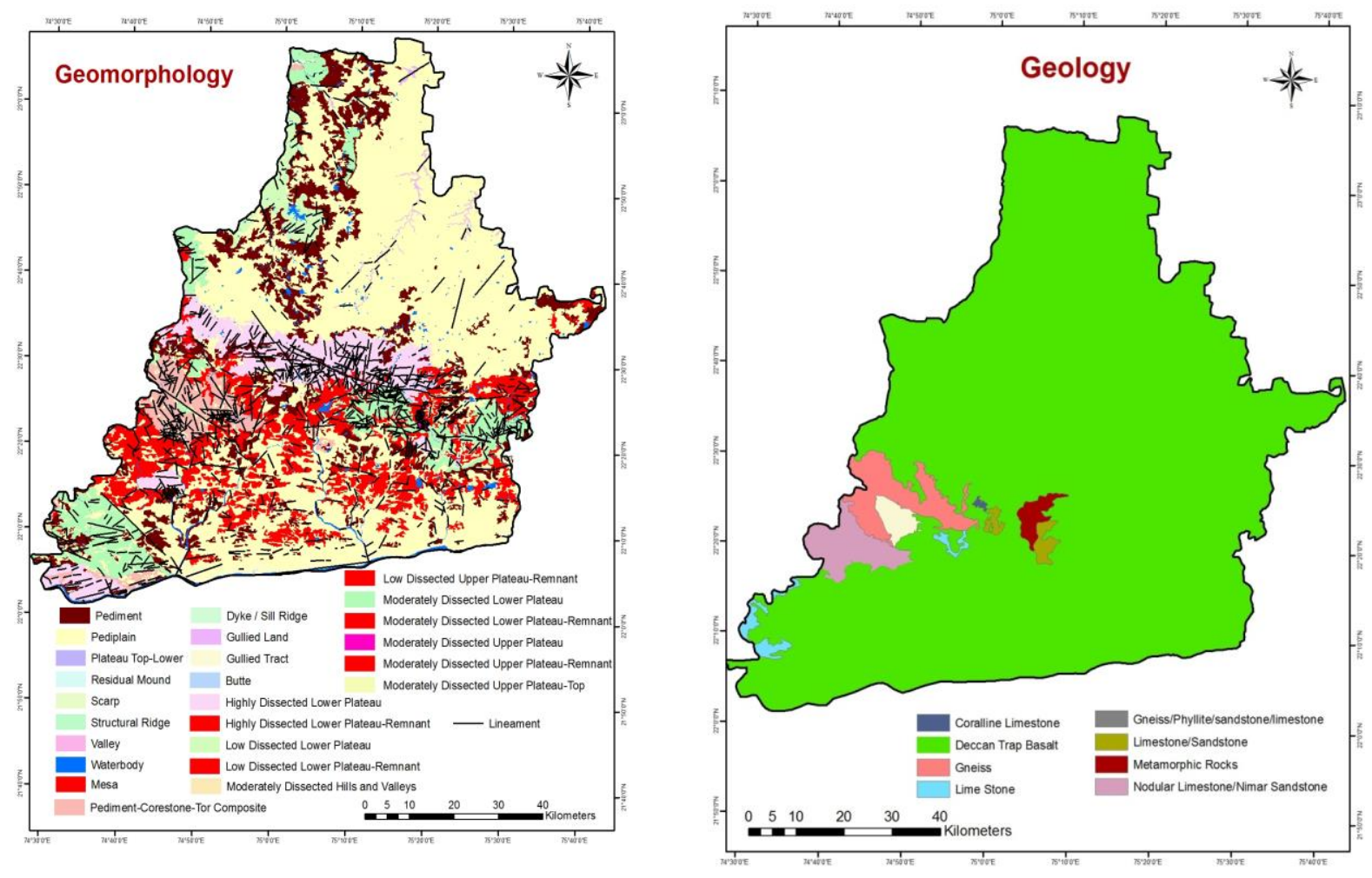

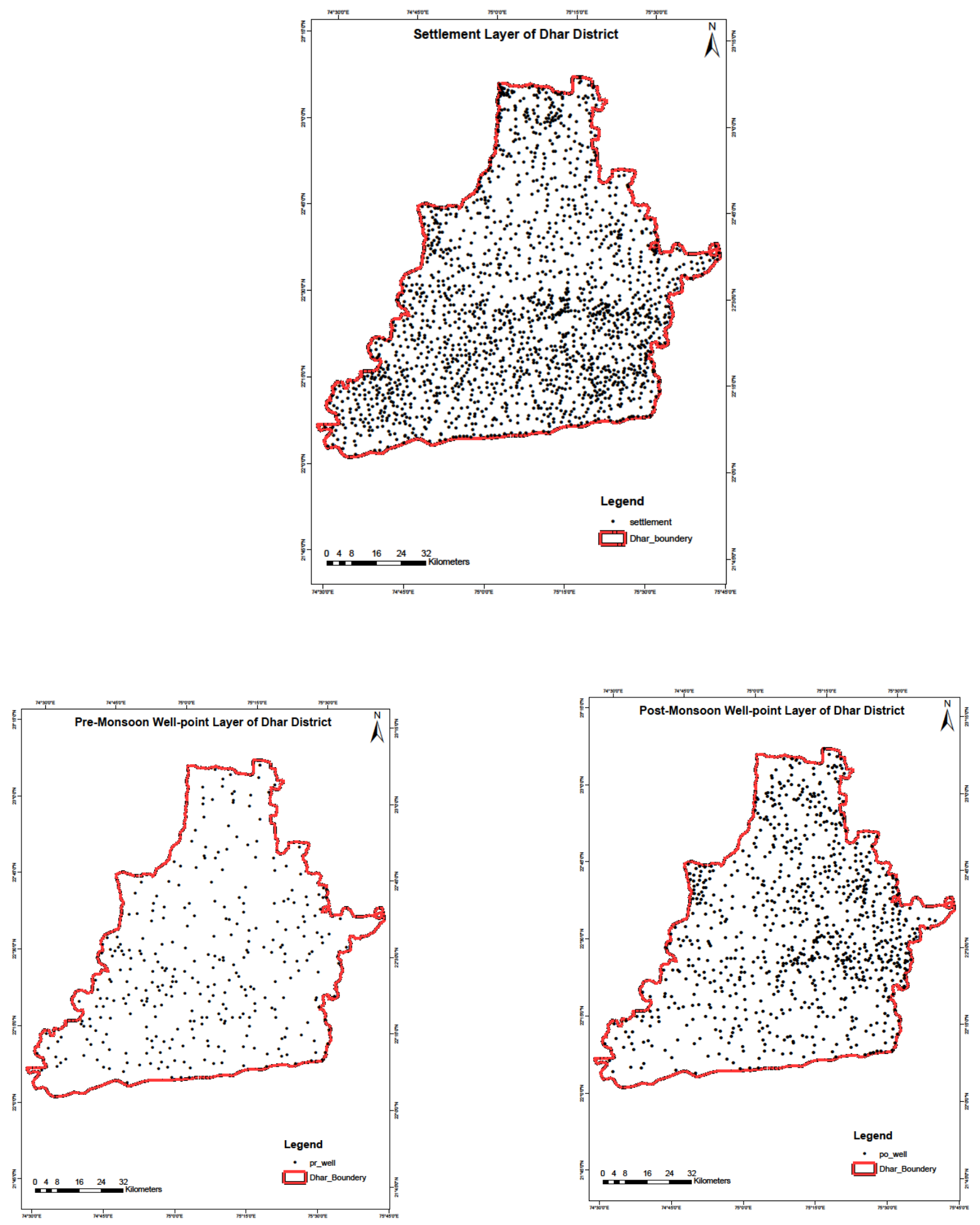

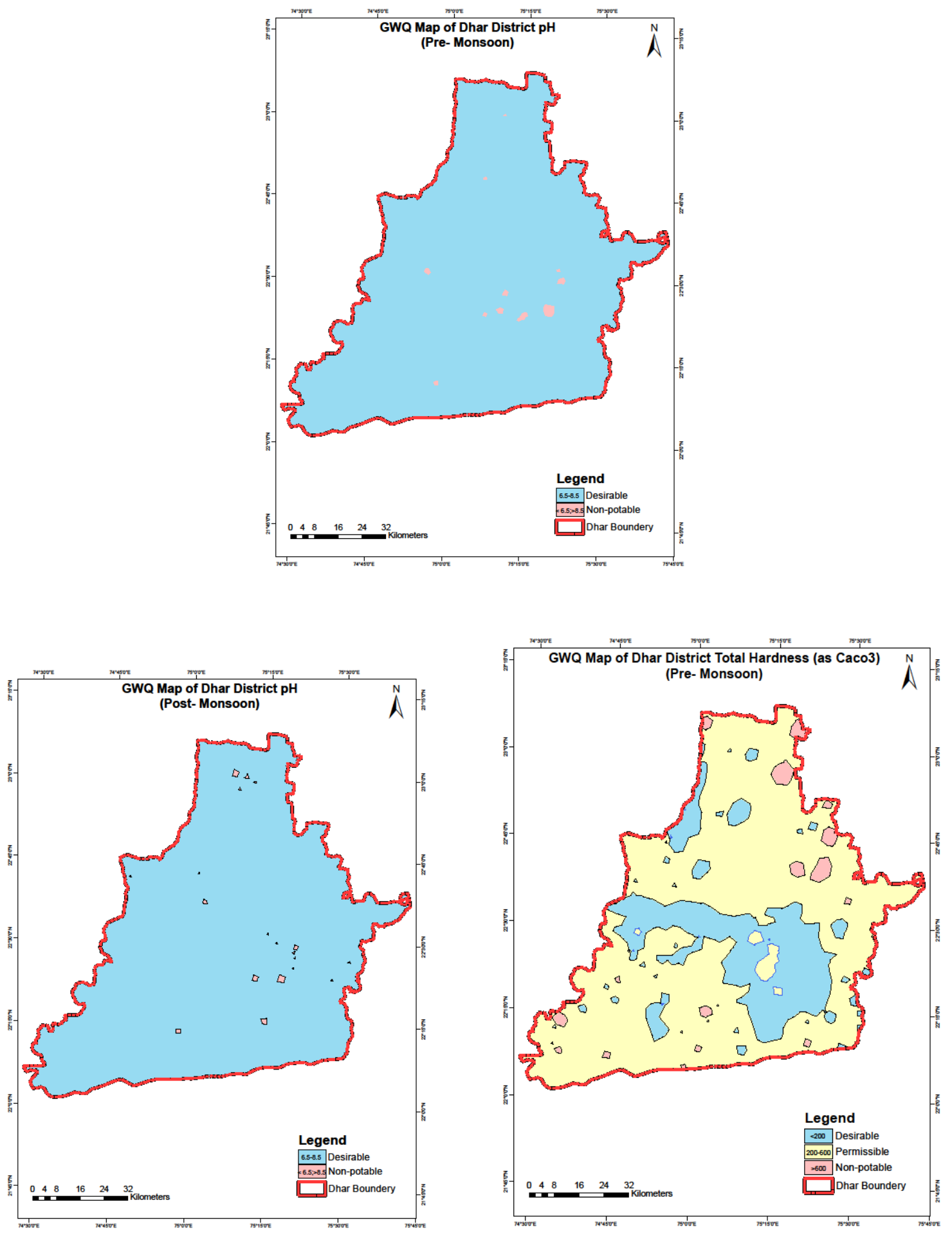

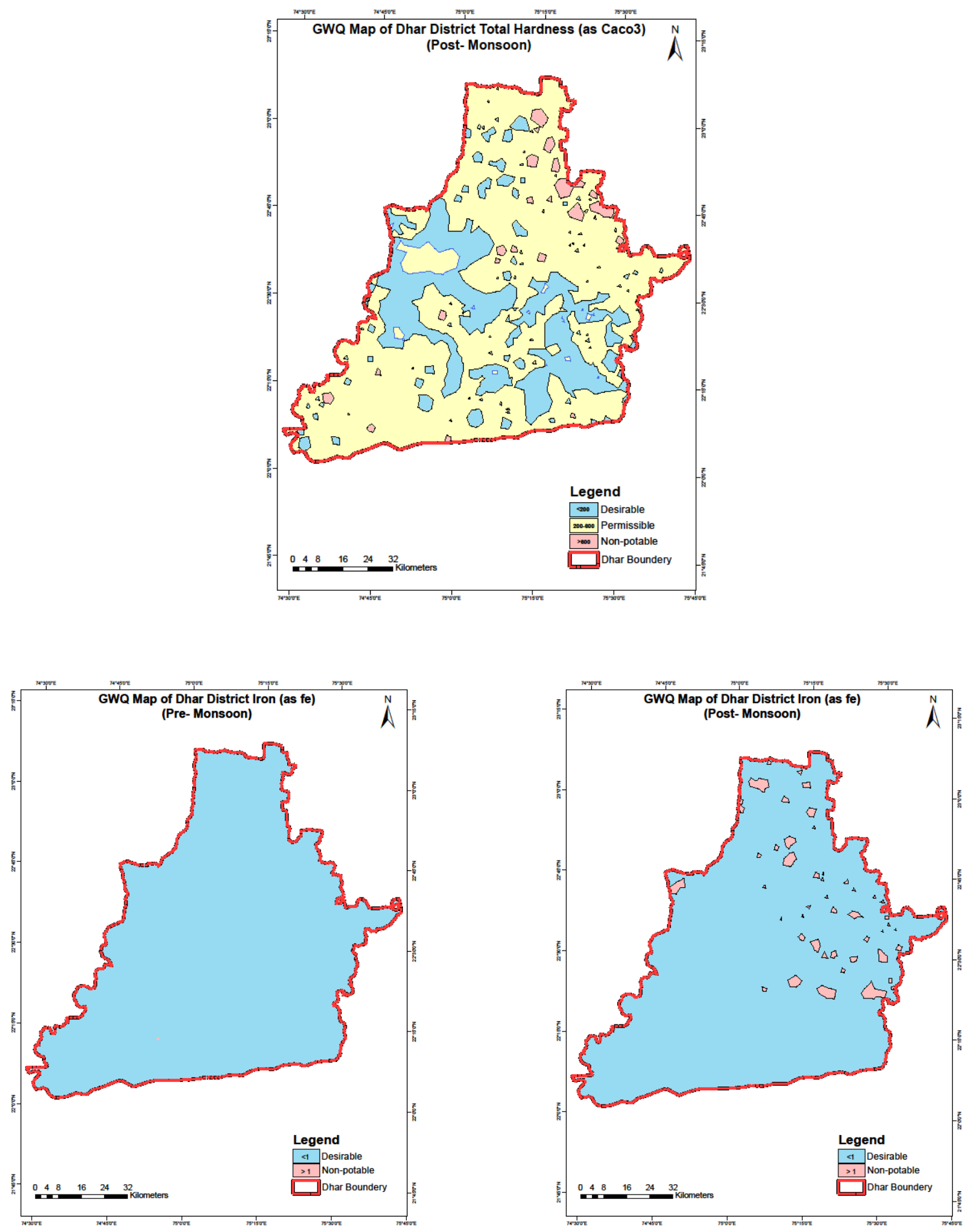

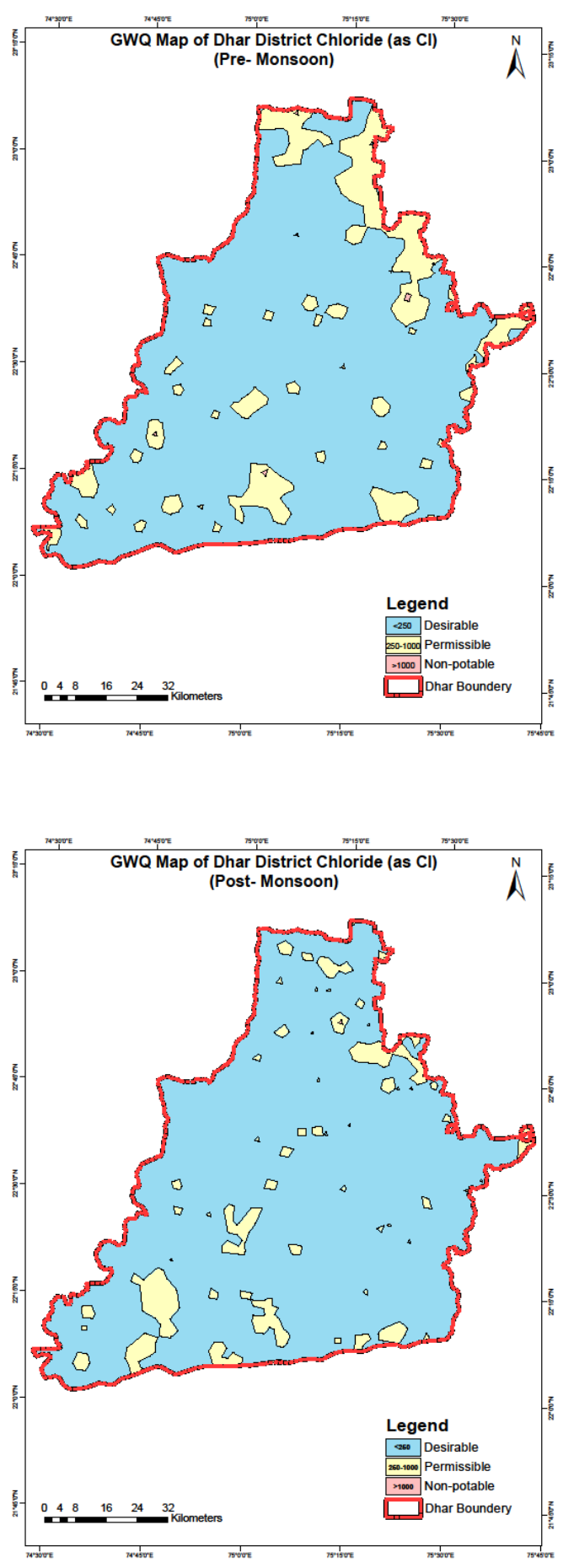

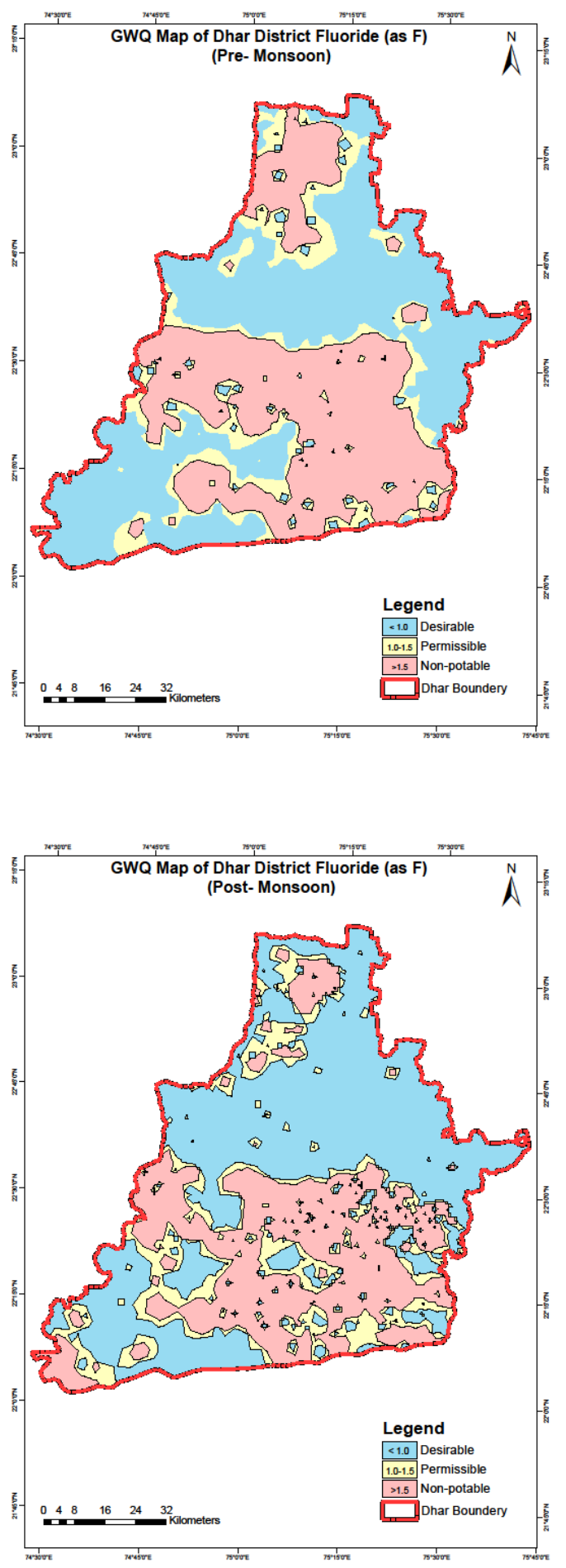

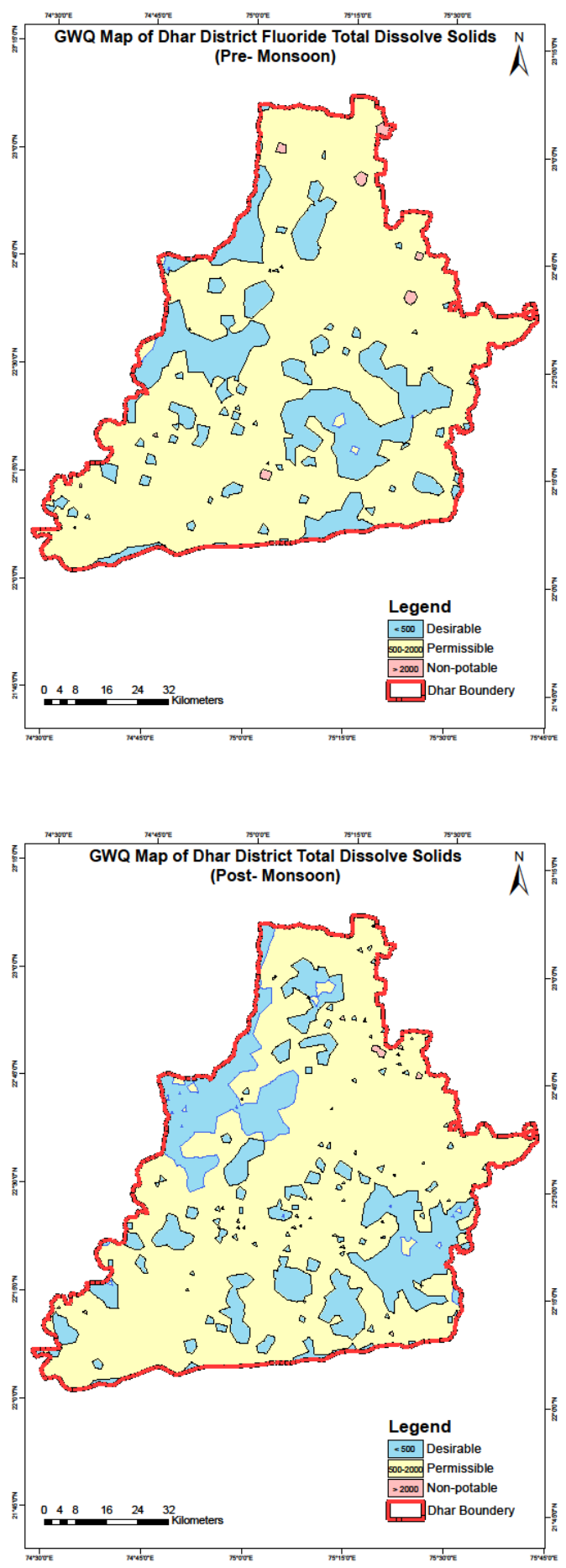

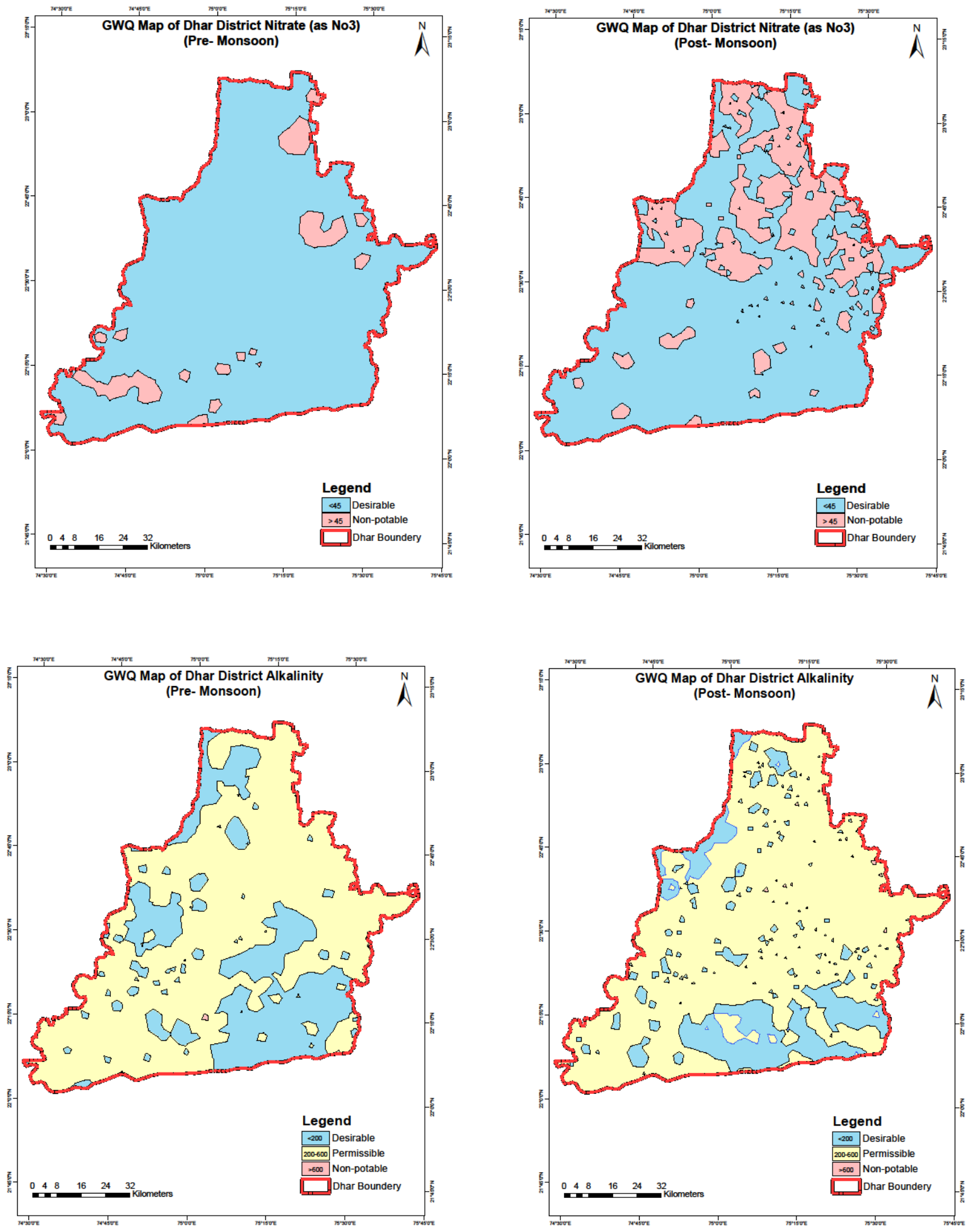

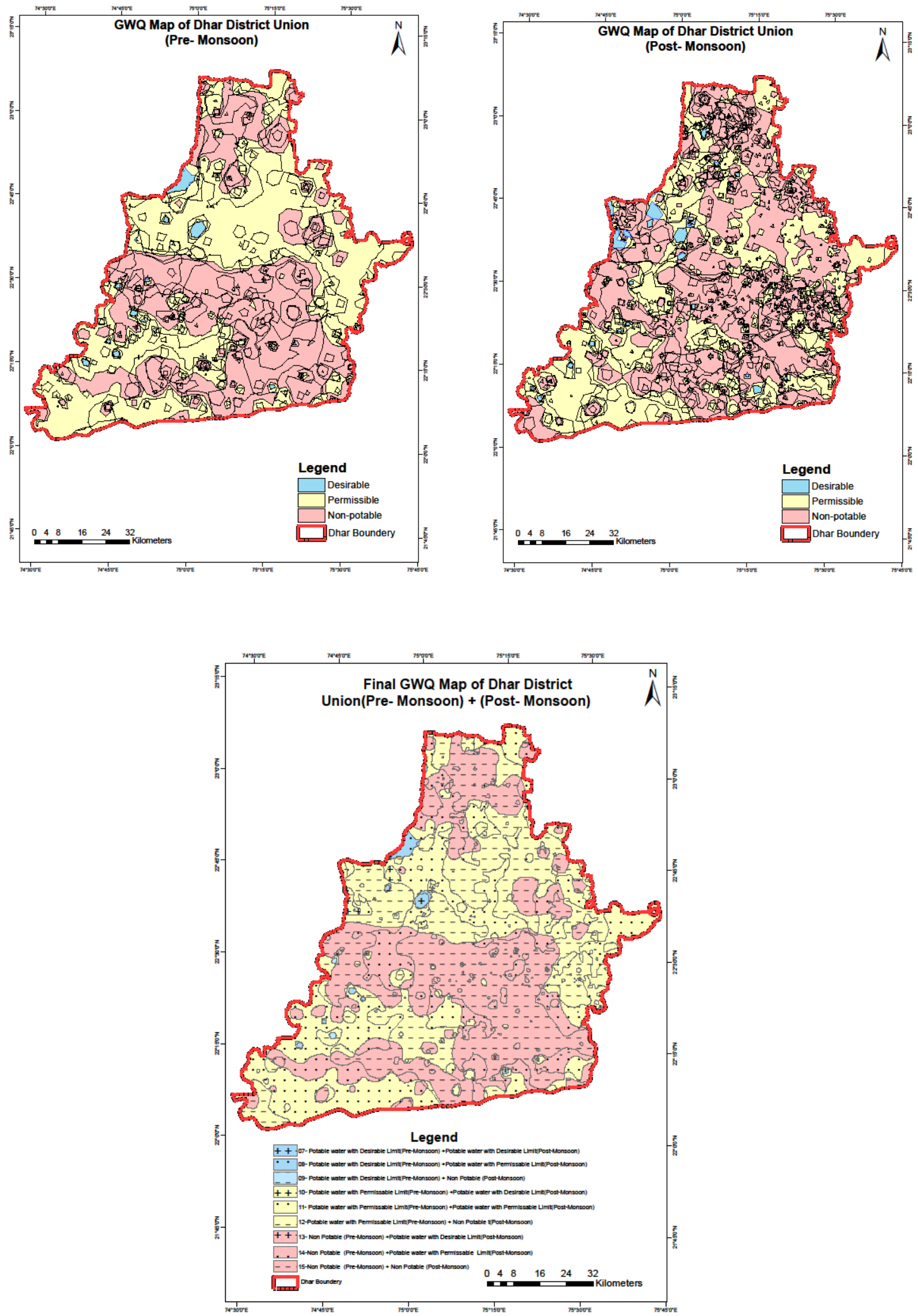

\section{Results and Discussion}

In the present study attempt has been made to generate the ground water quality class map by integration of Pre-monsoon ground water quality class map and Post-monsoon ground water quality class map. In the final ground water quality class map the following 9 classes have been identified. 
1) Non-Potable water (Pre-Monsoon) +Non-Potable water (Post-Monsoon).

Class-15;

This class covers an area of $\mathbf{2 5 3 4 . 5 8 ~ S q . k m}$ which is $\mathbf{3 1 . 1 1} \%$ of the total study area (8145.31 sq.km) and Out of $\mathbf{1 8 2 4}$ total Habitation, $\mathbf{5 8 4}$ Habitation which is $\mathbf{3 2 . 0 1 \%}$ are lying in this class. This area is mainly lies in the Northern \& Southern \& south eastern part of the study area lying mainly in the Basaltic region. This class is Non-Potable in both Pre \& Post monsoon season due to the concentration of the following elements - (1) $\mathbf{p H}$ - is ranging from 6.7 to $9.6 \mathrm{mg} / \mathrm{l}$ (2) Total Hardness is ranging from - 16 to $1510 \mathrm{mg} / \mathrm{l}$ (3) Iron is ranging from - 0.01 to $3.38 \mathrm{mg} / \mathrm{l}$ (4) Chloride is ranging from - 23 to $1261 \mathrm{mg} / 1$ (5) TDS is ranging from - 60 to $3300 \mathrm{mg} / \mathrm{l}$ (6) Nitrate is ranging from - 0.09 to 317.37 $\mathrm{mg} / 1(7)$ Fluoride is ranging from - 0.1 to $14 \mathrm{mg} / 1$ (8) Alkalinity is ranging from - 42 to $824 \mathrm{mg} / 1$

2) Non-Potable water (Pre-Monsoon) + Potable water with Permissible limits (Post-Monsoon)........... Class 14;

This class covers an area of $\mathbf{1 1 6 4 . 0 1}$ Sq.km which is $\mathbf{1 4 . 2 9 \%}$ of the total study area (8145.31 sq.km) and Out of $\mathbf{1 8 2 4}$ total Habitation, $\mathbf{3 0 6}$ Habitation which is $\mathbf{1 6 . 7 7 \%}$ are lying in this class. This area is mainly lies in the western \& south eastern part of the study area lying in the basaltic region and this class is Non-Potable water in Pre Monsoon due to the concentration of the following elements ranging from (1) Total Hardness- 68 to $2260 \mathrm{mg} / \mathrm{l}$ (2) Iron- 0.05 to $1.19 \mathrm{mg} / \mathrm{l}$ (3) Chloride- 6.04 to $1373 \mathrm{mg} / \mathrm{l}$ (4) TDS- 320 to $3700 \mathrm{mg} / \mathrm{l}$ (5) Nitrate- 02 to $220 \mathrm{mg} / \mathrm{l}$ (6) Fluoride- 0.21 to $8.3 \mathrm{mg} / \mathrm{l}$.

3) Non-Potable water(Pre-Monsoon) + Potable water with desirable limits(Post-Monsoon)

...Class-13;

This class covers an area of $\mathbf{1 0 . 5 4} \mathbf{~ S q . k m}$ which is $\mathbf{0 . 1 2 9} \%$ of the total study area and $\mathbf{0 9}$ Habitation which is $\mathbf{0 . 4 9 \%}$ are lying in this class. This class is Non-Potable in Pre-monsoon due to the concentration of the following elements ranging from -(1) $\mathbf{p H}-7.68$ to $8.78 \mathrm{mg} / \mathrm{l}$ (2) Fluoride- 2.82 to $5.11 \mathrm{mg} / \mathrm{l}$.

4) Potable water with Permissible limits (Pre-Monsoon) +Non-Potable water (Post-Monsoon). Class12;

This class covers an area of $\mathbf{2 0 2 7 . 0 7} \mathrm{Sq} \cdot \mathbf{k m}$ which is $\mathbf{2 4 . 8 8 \%}$ of the total study area and $\mathbf{3 6 9}$ Habitation which is $\mathbf{2 0 . 2 3 \%}$ are lying in this class. This area is mainly lies in the Northern \& central part of the study area lying in the basaltic region and this class is Non-Potable water in Post-monsoon season due to the concentration of the following elements ranging from - (1)) Total Hardness- 72 to $780 \mathrm{mg} / \mathrm{l}$ (2) Iron- 0.03 to $1.65 \mathrm{mg} / \mathrm{l}$ (3) Nitrate- 4.72 to $157.17 \mathrm{mg} / \mathrm{l}$ (4) Fluoride0.19 to $4.34 \mathrm{mg} / \mathrm{l}$.

5) Potable water with Permissible limits (Pre-Monsoon) + Potable water with Permissible limits (Post-Monsoon) Class-11;

This class covers an area of $\mathbf{2 2 5 4 . 0 1}$ Sq.km which IS $\mathbf{2 7 . 6 4} \%$ of the total study area and $\mathbf{5 0 2}$ Habitation which is $\mathbf{2 7 . 5 2 \%}$ lying in this class.

6) Potable water with Permissible limits (Pre-Monsoon) + Potable water with desirable limits (Post-Monsoon)............. Class-10;

This class covers an area of $\mathbf{7 3 . 8 5} \mathrm{Sq} . \mathbf{k m}$ which is $\mathbf{0 . 9 0 5} \%$ of the total study area. 28 habitation which is $\mathbf{1 . 5 3 \%}$ are lying in this class.

7) Potable water with desirable limits (Pre-Monsoon) + Non-Potable water (Post-Monsoon).................Class-9;

This class covers an area of $8.83 \mathrm{Sq} . \mathbf{k m}$ which is $\mathbf{0 . 1 0 8} \%$ of the total study area and $\mathbf{0 3}$ Habitation which is $\mathbf{0 . 1 6 \%}$ are lying in this class. This class is Non-Potable water (Post-Monsoon) season due to the concentration of the following elements. (1) Total Hardness- 196 to $796 \mathrm{mg} / \mathrm{l}$ (2) Nitrate- 13 to $133 \mathrm{mg} / \mathrm{l}$ (3) Fluoride- 0.75 to $2.59 \mathrm{mg} / \mathrm{l}$.

8) Potable water with desirable limits (Pre-Monsoon) + Potable water with Permissible limits (Post-Monsoon). Class- 8;

This class covers an area of $\mathbf{4 5 . 3 7} \mathrm{Sq} . \mathbf{k m}$ which is $\mathbf{0 . 5 5 \%}$ of the total study area and covers $\mathbf{1 5}$ Habitation which is $\mathbf{0 . 8 2} \%$ are lying in this class.

9) Potable water with desirable limits (Pre-Monsoon)+Potable water with desirable limits(Post-Monsoon)................... Class- 7;

This class covers an area of $\mathbf{2 7 . 0 2} \mathbf{~ S q . k m}$ which is $\mathbf{0 . 3 3 \%}$ of the total study area and it has only $\mathbf{0 8}$ Habitation which is $\mathbf{0 . 4 3 \%}$ are lying in this class. 


\section{Area And Habitation Percentage}
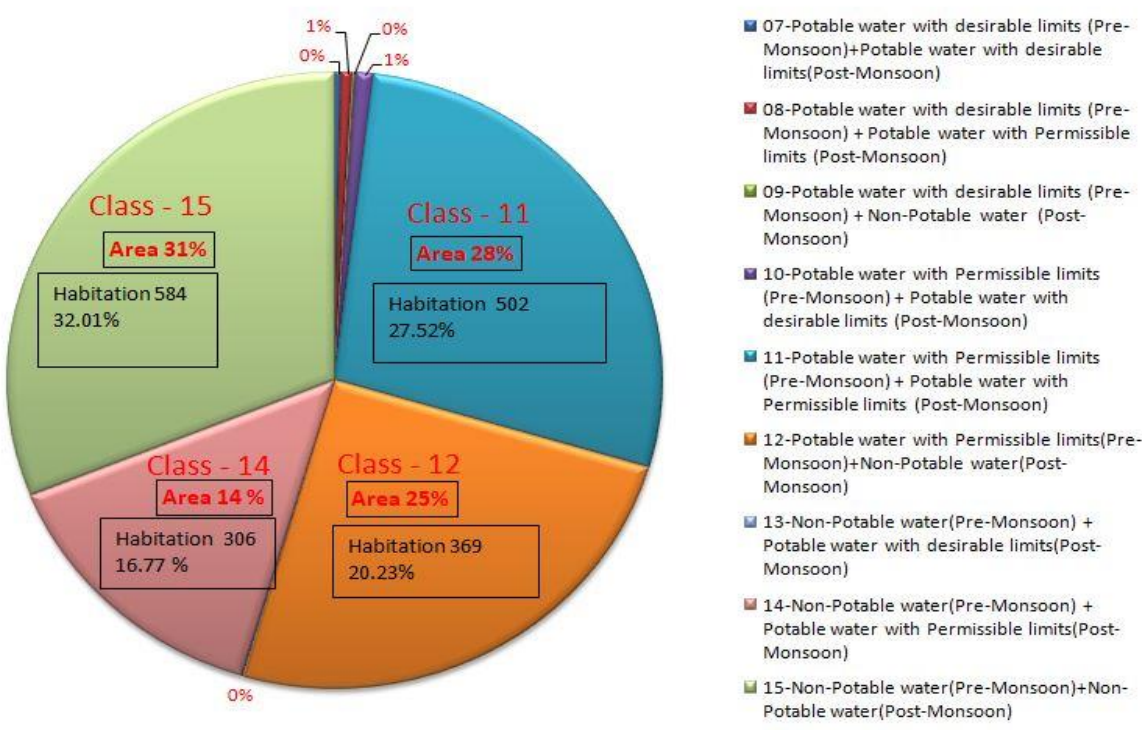

घ08-Potable water with desirable limits (PreMonsoon) + Potable water with Permissible limits (Post-Monsoon)

09-Potable water with desirable limits (PreMonsoon) + Non-Potable water (PostMonsoon)

10-Potable water with Permissible limits (Pre-Monsoon) + Potable water with desirable limits (Post-Monsoon)

11-Potable water with Permissible limits (Pre-Monsoon) + Potable water with Permissible limits (Post-Monsoon)

12-Potable water with Permissible limits(PreMonsoon)+Non-Potable water(PostMonsoon)

13-Non-Potable water(Pre-Monsoon) + Potable water with desirable limits(PostMonsoon)

14-Non-Potable water(Pre-Monsoon) + Potable water with Permissible limits(PostMonsoon)

15-Non-Potable water(Pre-Monsoon)+NonPotable water(Post-Monsoon)

Figure 1. Area and habitation percentage

\section{FLUORIDE AFFECTED HABITATION AND PERCENTAGE (SEASON-WISE) DHAR DISTRICT,MADHYA PRADESH}

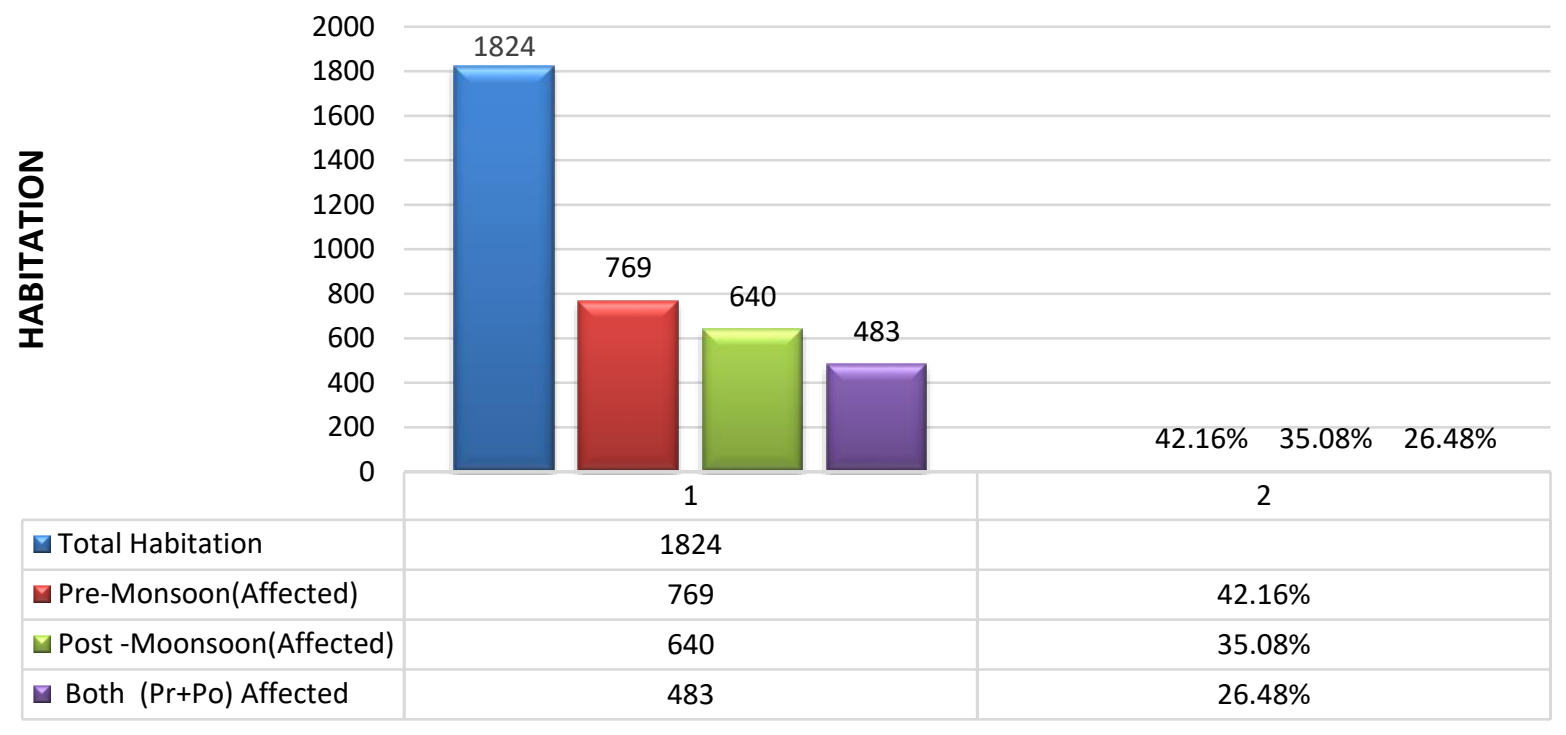

Figure 2. Fluoride affected habitation and percentage (season-wise) Dhar district, Madhya Pradesh 


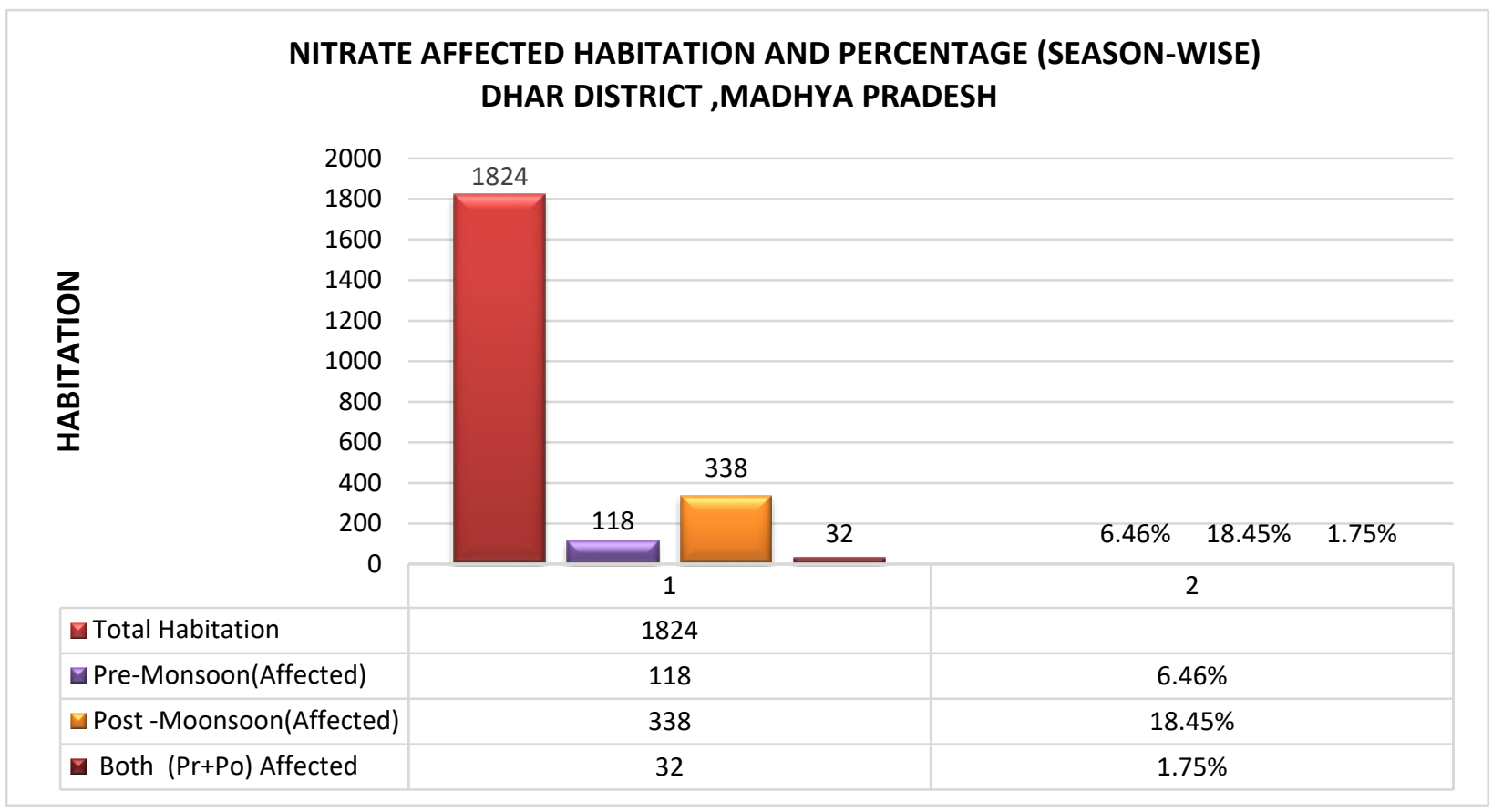

Figure 3. Nitrate affected habitation and percentage (season-wise) Dhar district, Madhya Pradesh

\begin{tabular}{|l|l|l|l|}
\hline \multicolumn{1}{|c|}{ TOTAL HARDNESS AFFECTED HABITATION \& PERCENTAGE (SEASON-WISE) } \\
DHAR DISTRICT, MADHYA PRADESH
\end{tabular}

Figure 4. Total hardness affected habitation and percentage (season-wise) Dhar district, Madhya Pradesh

The Fluoride is the main element which is being found beyond permissible limit in the Dhar district. In Dhar district out of the total 1824 Habitations, In pre- Monsoon season 769 Habitation which is $\mathbf{4 2 . 1 6 \%}$, while in post-Monsoon season 640 Habitations which is $\mathbf{3 5 . 0 8} \%$ are affected by excess of Fluoride, while in Both pre and post - Monsoon seasons (Union), 483 Habitations which is $\mathbf{2 6 . 4 8} \%$ of the total Habitations are affected by excess of Fluoride which is non-potable.

Nitrate is the second element which is being found beyond permissible limit in the Dhar district. In Dhar district out of the total 1824 Habitations, In pre-Monsoon season 118 Habitation which is $\mathbf{6 . 4 6} \%$, while in post-Monsoon season 338 Habitations which is $\mathbf{1 8 . 4 5} \%$ are affected by excess of Nitrate, while in Both pre and post Monsoon seasons (Union), 32 Habitations which is $\mathbf{1 . 7 5 \%}$, of the total Habitations are affected by excess of Nitrate which is non-potable.

Total Hardness is the third element which is being found beyond permissible limit in the Dhar district. In 
pre-Monsoon season 58 Habitation which is $3.17 \%$, while in post-Monsoon season 41 Habitations which is $2.24 \%$ are affected by excess of total Hardness while in Both pre and post Monsoon seasons (Union), 32 Habitations which is $\mathbf{0 . 5 4} \%$ of the total Habitations are affected by excess of total Hardness which is non-potable.

pH is the Fourth element which is being found beyond permissible limit in the Dhar district. In pre-Monsoon season 27 Habitation which is $\mathbf{1 . 4 8 \%}$, while in post-Monsoon season 15 Habitations which is $0.82 \%$ are affected by excess of $\mathrm{pH}$, while in Both pre and post- Monsoon seasons (Union ), 10 Habitations which is $\mathbf{0 . 5 4 \%}$ of the total Habitations are affected by excess of $\mathrm{pH}$ which is non-potable.

Iron(fe) is the fifth element which is being found beyond permissible limit in the Dhar district. In pre-Monsoon season 8 Habitation which is $0.43 \%$, while in post-Monsoon season 60 Habitations which $3.28 \%$ are affected by excess of Iron(fe), while in Both pre and post Monsoon seasons (Union), 1 Habitation which is $\mathbf{0 . 0 5 4 \%}$ of the total Habitations are affected by excess of Iron(fe) which is non-potable.

\section{Conclusion}

Based on the correlation between water quality and the existing geological formation, the problematic areas were identified. The results indicate that certain parameters mainly Fluorides, Nitrates, Total Hardness, pH and TDS were beyond the permissible limits in Dhar district.

The analysis of the results drawn at various stages of the work revealed that integration of Remote Sensing and GIS are effective tools for the preparation of various digital thematic layers and maps showing spatial distribution of various water quality parameters. Monitoring of pollution patterns and its trends with respect to urbanization is an important task for achieving sustainable management of groundwater. Spatial distribution maps of various pollution parameters are used to demarcate the locational distribution of water pollutants in a comprehensive manner and help in suggesting groundwater pollution control and remedial measures in a holistic way.

The continued consumption of fluoride in excess to $1.5 \mathrm{mg} / \mathrm{l}$ either through water, air or food items for a long time may cause dental, non- skeletal and skeletal fluorosis (Chand Dinesh, 2001). Fluoride > $1.5 \mathrm{mg} / \mathrm{l}$ Fluoride in excess can cause several ailments viz. Neurological, Muscular, Allergic, gastrointestinal effects, urinary problem, headache. Fluoride $>3 \mathrm{mg} / \mathrm{l}$ can result skeletal fluorosis and skeletal abnormalities. Fluoride $>10 \mathrm{mg} / \mathrm{l}$ over a long period can result in crippling fluorosis.

\section{References}

Chand, D. (2001). Fluoride in Drinking Water: A Challenge of the millennium, International workshop on Fluoride in Drinking Water: Strategies. Management \& Mitigation.

District Resource Map Dhar District, (2000). Published by Geological Survey of India.

Ground Water Quality Mapping, Rajiv Gandhi National Drinking Water Mission (RGNDWM), (2011). Methodology Manual, Hydrogeology Group, NRSA, National Remote Sensing Centre, Indian Space Research Organisation, Dept. of Space, Govt. of India, Hyderabad.

Jain, R. (2013). Ground Water Quality Mappping around Keolari in Seoni District of M.P. using Remote Sensing and GIS Techniques, Project Report for M.Tech. degree at NIT Warangal.

Jalali, M. (2005). Nitrates leaching from agricultural land in Hamadan, Western Iran. Agriculture, Ecosystems and Environment, 110, 210-218. https://doi.org/10.1016/j.agee.2005.04.011

National Geomorphological and Lineament Mapping on 1:50,000 scale, (2010). Manual, Geological Survey of India Ministry of Mines Government of India and Indian Space Research Organisation Department of Space Government of India.

Olajire, A. A., \& Imeokparia F. E. (2001). Water quality assessment of Osun River: Studies on inorganic nutrients. Environ. Monitor. Assess., 69(1), 17-28. https://doi.org/10.1023/A:1010796410829

Saha, D., Dhar, Y. R., \& Sikdar, P. K. (2008). Geochemical Evolution of Groundwater in the Pleistocene Aquifers of South Ganga Plain, Bihar. Jour. Geol. Soc., 71, 473-482.

Sarala, C., \& Ravi, B. P. (2012). Assessment of Groundwater Quality Parameters in and around Jawaharnagar, Hyderabad. International Journal of Scientific and Research Publications, 2(10), October 20121 ISSN 2250-3153.

\section{Copyrights}

Copyright for this article is retained by the author(s), with first publication rights granted to the journal.

This is an open-access article distributed under the terms and conditions of the Creative Commons Attribution license (http://creativecommons.org/licenses/by/4.0/). 